(1990).

But the grandest scholarly accomplishment for this Harvard Ph.D. (his dissertation was in English Renaissance studies) is the six-volume Walt Whitman: The Correspondence (1961-1977), so thoroughly and accurately annotated as to constitute a living biography of the poet. As a Whitman scholar for many years and the author of the latest biography, I can attest to the absolute reliability of this monumental work. Ed continued to work on collecting stray Whitman letters, adding a supplement to his six volumes with a special double issue of $W W Q R$ in 1991 that gathered nearly fifty newly discovered letters. Ed's work continues to be built upon and added to: we will keep finding more letters (as Ted Genoways's collection in this issue of WWQR amply demonstrates), but Ed's edition remains the foundation and main structure.

Edwin Haviland Miller recharted the landscape for Whitman scholars and along the way wrote on other major figures in American (as well as English) literature, including a controversial biography of Melville (1975). At the time he was stricken with Alzheimer's he was hard at work on a biography of Frank Norris. He was an eminent scholar, an excellent writer, and a good friend.

-JEROME LOVING

\title{
THE RETURN OF THE MICKLE STREET REVIEW
}

Camden was originally an accident, but I shall never be sorry I was left over in Camden. It has brought me blessed returns. - Walt Whitman

Named for the street in Camden, New Jersey, on which Whitman lived for the last eight years of his life, The Mickle Street Review, a peer-reviewed electronic journal published by the English department at Rutgers University-Camden in cooperation with the Walt Whitman Program in American Studies, seeks to re-imagine Whitman's place in the American scene and investigate through various media the issues that he raised in his poetry and prose. Edited by Tyler Hoffman, an assistant professor of American literature and cultural studies, along with J.T. Barbarese, an assistant professor of creative writing and American literature, $M S R$ features some of the best and most exciting work currently being done in the fields of Whitman Studies and American Studies, with a focus on the region in which Whitman lived and worked, from New York City to Washington, D.C., centering on his home in Camden. The journal's mix of poetry, fiction, essays, archival documents, reviews, and visual art seeks to facilitate interdisciplinary exchanges among creative writers, artists, teachers, and scholars interested in American literature and culture in Whitman's day and beyond.

The Mickle Street Review was begun in 1979 by Geoffrey Sill and Frank McQuilkin as a joint project of the Walt Whitman House, a State of New Jersey historic site, and Rutgers University in Camden. The journal ceased publication in 1991 for financial reasons. In its new electronic incarnation, The Mickle Street Review (http://www.micklestreet.rutgers.edu) supports both the American Studies and the creative writing programs at the graduate and undergraduate schools of Rutgers-Camden and continues in its alliance with the 
Walt Whitman House. It is part of the Camden On-line Poetry Project, an umbrella organization that coordinates the activities of several related on-line publishing projects sponsored by the Rutgers-Camden English department.

For its part, $M S R$ features in its first on-line issue a variety of pieces highlighting the theme of museums and memoirs, two important cultural forms in the framing of American history and in discussions of Whitman in and as history. Issues of identity, memory, and performance, which are integrally related to these forms, are taken up, teased out, and figured in a range of texts. Focusing on the connections between a poet and the place that he or she inhabits, the issue draws on the knowledge and experience of the curators of regional historical societies and historic sites to show how such places may help the public to interpret the poet's work. While some of the pieces in the issue are squarely about Whitman and his experiences in the world, others are tangential to Whitman, offering windows into American life and letters in the nineteenth and early twentieth centuries.

From the start, the mission of $M S R$ was to provide common ground for readers with an interest in Walt Whitman or the subjects that he wrote about. The new electronic $M S R$ will be even broader in scope, seeking to initiate a dialogue among diverse speakers and audiences who might otherwise not come into contact with each other. Spinning out filaments of its own, this time through a web much wider than that available to Whitman, The Mickle Street Review will connect people who may have nothing in common except to have been, at some point, lifted out of themselves by Whitman's overwhelming power. To have read Whitman, even once, is to join a vast network whose members, from the least to the most famous, have much to say to each other. The mission of The Mickle Street Review is to be the forum in which that dialogue happens. 